\title{
Gotong Royong
}

Nur Azizah Ainun Razak

NIM: 9173770410043

Email: andiainun606@gmail.com

1.Bentuk Kegiatan

Gotong Royong.

\section{Lokasi}

Kantor Desa Balangloe Tarowang

3.Hari/Tanggal Waktu

Sabtu 26 September 2020 08:00

\section{Peserta yang Dilibatkan} Mahasiswa Kuliah Kerja Lapang Plus (KKLP)

\section{Alasan Diadakannya}

Dengan adanya Gotong Royong dapat menciptakan hubungan yang harmonis antar mahasiswa,juga

terciptanya ketentraman dan ketertiban bersama sehingga menciptakan kehidupan

yang

Demokrasi.

\section{Tujuan dan Manfaat}

Tujuan Kebersamaan yang terjalin dalam gotong royong sekaligus melahirkan persatuan antar anggota dengan persatuan yang ada, dimasyarakat menjadi lebih kuat dan mampu menghadapi permasalahan yang muncul Sedangkan manfaatnya yaitu agar lingkungan kita,dapat dirasakan kebersihan dan keindahannya

\section{Produk Kegiatan (Jika} Ada)

Sapu lidi,sapu iju,skop sampah

\section{Deskripsi Kegiatan}


Diadakannya kegiatan gotong royong bersama mahasiswa kegiatan ini rutin diadakan untuk mempertahankan kebersihan kantor desa yang selama ini sudah mengalami peningkatan.kepala Desa mengharapkan agar kegiatan ini bisa dilakukan secara rukun agar lingkungan kantor desa menjadi bersih,indah, dan tertata 


\section{Referensi Wajib}

- HERIANTO, H., \& Amir, A. S. (2020, September 10). Pedoman Pelaksanaan Kuliah Kerja Lapangan Plus (KKLP) Mahasiswa STIE dan STKIP YAPTI Jeneponto. https://doi.org/10.31219/osf.io/7dvpk 